\title{
REFLECTIONS ON THE ACCOUNTING PROFESSION IN RUSSIA IN THE LATE NINETEENTH - EARLY TWENTIETH CENTURY
}

\author{
Irina N. Lvova \\ St. Petersburg State University of Economics, Russia \\ Dina A. Lvova \\ St. Petersburg State University, Russia
}

\begin{abstract}
Accounting profession in Russia has been taking shape since the late nineteenth century. That period is marked by discussions about the subject matter of the profession and establishment of the Institute of Accountants. Reflections arising from these discussions are an interesting topic of modern research. They gave rise to a whole variety of profession-related images (e.g. a 'cultural activist on the economic ground', 'artist and organizer', 'commerce officer', etc.), facilitating the moulding of the Institute rules.

The present research is based on extensive materials of those discussions published in the journals Schetovodstvo, Kommercheskoye Obrazovaniye, Kommercheskaya Shkola i Zhizn and others. Among other sources were the materials from Russian educationalists' conventions on technical and professional education, and recommendations of directors of business schools from the series of meetings convened in the late nineteenth and early twentieth century. Some of resources available were not used in the course of modern studies, nor were they ever examined from this perspective.
\end{abstract}

This paper attempts to provide a critical analysis of the past discussions. We tended to correlate these images with the reality in order to see how productive such discussions can be and which impact on the development of the profession they can have.

Keywords accounting profession, image of the profession, Institute of Chartered Accountants

JEL code: M420, N330, A290

\section{Introduction}

The emergence of accounting as a profession in Russia is not related to any specific date or event. It started evolving in the late nineteenth - early twentieth century, when the abolition of serfdom boosted the economy. The creation of large trade and industrial enterprises transformed the views on the way accountancy should be organised. The duty of keeping the books imposed by the law on business owners was gradually delegated to hired accounting professionals.

Businessmen and employed accountants became a substantial part of society, though their role and activity still remained rather vague in the public mind. Society, with its established vision of noble professions (of a doctor, teacher, engineer, etc.), could not come to a single stance on commerce as an occupation. In the late nineteenth century, it was still regarded as low-grade and indecent for a well-educated and cultivated individual. Zamyatin, one of the authors of the journal Schetovodstvo (Accountancy), articulated a wide-spread view of commerce in the following way (1893, p. 338): 'trading, swearing, packing goods, and receiving money is so simple that it does not seem to require any special training'.

The question of who these people are, what they should be like and what they should do was put up for public discussion at least twice and at least on two occasions. The first occasion was determined by a reform of commercial (economic) education initiated by Sergei Witte, Minister of Finance (1849-1915). It reflected the need of industry and commerce for well- 
educated and trained entrepreneurs. The second occasion was triggered by the efforts aimed at creating professional associations of accountants after similar institutes of chartered accountants in Scotland ${ }^{1}$ and England ${ }^{2}$.

Our original intention to connect history of accounting profession in Russia with the social and cultural identification was inspired by the works of Y. V. Sokolov (2003), J. R. Edwards and S. P. Walker (2010) and M. Anderson and S. P. Walker (2009). The area of our focus was also determined by the works on the history of accounting education of J. R. Edwards (2010, 2011), P. Clarke (2008), G. D. Carnegie (2009) in English language area, of J. Alver and L. Alver (2016) in Estonia and S. Karelskaya and E. Zuga in Russia (2015). The history of the profession is usually linked to the emergence of the professional associations (institutes). The works of M. Anderson, J. R. Edwards and R. A. Chandler (2005), P. Boys (1994), R. J. Briston and M. J. M. Kedslie (1986), T. A. Lee (1991, 2004), K. M. Macdonald (1984), K. P. McMillan (1999), C. Ramirez (2001), S. P. Walker (1995, 1999), H. Willmott, (1986) and other authors prove convincingly that it was those institutes that created the profession in the way we understand it today.

\section{Image of a Merchant and Accountant in the Discussions Concerned with Education}

Foundations for the reform of commercial education were laid in 1894, with its fundamental document, Provision on Commercial Educational Institutions, adopted two years later, in 1896. It set a legislative framework for a rapid growth of trade schools, commercial colleges, and trade classes $^{3}$. Over just the first six years after it came into force, 147 educational institutions of this profile were opened throughout the Russian Empire, with over 20,600 people studying there (Ministry of Finance, 1902, p. 605).

Discussions about the subject matter of commercial education and commercial professions were led at the meetings of Russian specialists on engineering and vocational education as well as at the conferences of the leaders and representatives of the boards of trustees of commercial educational institutions, frequently convened since the 1890s. Periodicals were also actively involved in the debates, among them such journals as Vestnik Vospitaniya (Education Bulletin), Russkaya Shkola (Russian School), Kommercheskoye Obrazovaniye (Commercial Education), Kommercheskaya Shkola i Zhizn (Commercial School and Life), Schetovodstvo (Accountancy), and others.

\footnotetext{
${ }^{1}$ In the nineteenth century, there were three associations of chartered accountants functioning in Scotland (see Brown, 1905; ICAS, 1954): The Edinburgh Society of Accountants (registered in 1854), The Glasgow Institute of Accountants and Actuaries (registered in 1855), and The Aberdeen Society of Accountants (registered in 1867).

${ }^{2}$ In the 1870s, five professional associations of accountants were formed in England (see Boys, 2004): The Incorporated Society of Liverpool Accountants (1870), The Institute of Accountants in London (1870), The Manchester Institute of Accountants (1871), The Society of Accountants in England (1872), and The Sheffield Institute of Accountants (1877).

${ }^{3}$ Trade classes were organized for the employees of commercial and industrial firms who have reached the age of twelve. They provided basic commercial knowledge needed in trading. Trade schools prepared individuals lacking experience for working in commercial and industrial institutions. They were divided into single-class ones (with a one-year period of study) and three-class ones (lasting for three years). The age and educational requirements were set for those willing to enter trade schools. Commercial colleges could be seven- and threeclass ones. The seven-class ones provided both general and commercial education, with the three-class ones providing only commercial education. The requirements for those entering these educational institutions were similar to the requirements for entering non-classical secondary schools. The courses of commercial knowledge taught various commercial disciplines including accountancy. Students taking them had to produce a certificate of at least secondary education.
} 
Because of uncertainty related to the profession, requirements to the knowledge and skills of trade school graduates were not strictly outlined yet and were determined by the images formed by those individuals who were more or less interested in the development of education. The variety of images developed by them shaped the concept of a profession of the future, as it was viewed more than one hundred years ago.

The most typical image of an accountant and merchant, as adopted by many educated members of society, was the one of a 'cultural activist on the economic ground'. This phrase combines three words: 'culture', 'activist', and 'economic ground'. The term 'culture' was initially associated in Russian with the notion of 'good education' (Renofanz, 1837, p. 139); however, its meaning evolved by the second half of the nineteenth century. Dahl (1956, p. 217), for instance, interprets one of its meanings as both mental and moral education. An activist can be defined as a person who has distinguished himself/herself in any kind of public activity (Ozhegov and Shvedova, 2004). Using this word to describe a graduate of a business school gives them certain responsibilities for society, with their profession entailing a public burden. Famous professor Sakharov wrote (1906, p.109): 'Business schools aim to rear a businessman capable of having their own initiative and becoming a head of a big enterprise, fully aware of their public responsibilities'.

Untypical for the modern language, the word combination 'economic ground' is a figurative expression aiming in this case to define the basis or environment of the activity of 'culture bearers', the students of commercial colleges. At the turn of the twentieth century, the Russian economic ground had those wholesome natural historical conditions in which the seeds of economic culture could germinate. An activist on this ground could thus be compared to the sower from the Bible. Similarly to good soil described in the Bible ${ }^{4}$, he was destined to sow 'the people's field with knowledge'

Economic growth gave hope for optimistic forecasts about the development of the profession. The most challenging one was proposed by V. D. Belov (1893), a famous accounting theoretician. Ahead of his time, he justified the need for academic training in accounting and its practical meaning. Belov believed that it was useful and necessary not in the narrow sense that an experienced and competent accountant could not do without it. Most importantly, academic training helps to reach the desired level of accounting perfection. Belov developed an image of an accountant whom he dubbed an 'artist and organizer' (1893, p. 52). Such accountants, as envisioned by their creator, should not limit themselves to generally accepted rules or bookkeeping techniques. Theoretical literature and exemplary practical writings are nothing but the necessary material for them. All the rest is a matter of personal creativity.

Searching for a more specific definition of professional activity typical for commercial professions, some members of discussions made use of analogies. V. Shimanovsky (1908), one of the authors of the journal Kommercheskoye Obrazovaniye, for instance, made an attempt to compare a merchant with an officer. From the very first days, he believed, students of commercial schools had to be taught knighthood, courage, sense of duty, contempt for danger, honour, and other military valours. "Commerce officers", as he would call the merchant elite, had to be honest in terms of their ideals and profession. Flawless professional honesty, as the only rational technique in the light of competition, he supposed, had to inevitably replace the old professional credo "if you don't cheat, you won't sell". The next thing of importance for a tradesman is thrift. However, it had to be understood not as methods merchants previously used to line their pockets. Thrift was opposed to thoughtlessness and

\footnotetext{
${ }^{4}$ According to the Gospel, 'Others, like seed sown on good soil, hear the word, accept it, and produce a crop some thirty, some sixty, some a hundred times what was sown' (New International Version. Mark 4:20).

${ }^{5}$ Quote from Nekrasov's poem To the Sowers (1876).
} 
extravagance of the new generation of merchants. And finally commercial school was to teach its students respect for the title of a businessman. We should give credit to Shimanovsky for promoting private commercial practice as an activity of public importance. He believed that a merchant is primarily a servant of his state which entrusts him with its most precious treasure, a product of labour (of both its native and foreign peoples); meanwhile a dishonest businessman is a criminal before the society and the state like a soldier who violated the oath. A businessman is also a cultural agent since he is the leader and driver of people's tastes and needs as well as of industrial ingenuity (1908, p. 293-297).

\section{Image of an Accountant in the Discussions Concerned with the Creation of Institute of Accountants}

In search of professional identification, supporters of the Institute of Accountants turned their attention to the prototypes of today's attorneys at law. They evolved as an institution attached to the Russian court as a result of the court reform of 1864 . They were authorised to handle criminal and civil cases, providing defence to defendants in criminal proceedings. The Institute of Accountants was supposed to be based after the corporation of attorneys at law. V.A. Milyaev (1890), who was engaged in a journal discussion about the Institute of Accountants, articulated the goal of the new corporation, reflecting the ideals of the profession. He called upon "bringing to the class of accountants the awareness of moral responsibility for the government and society, creating the profession of individuals representing faithful assurance of knowledge and honest beliefs" (1890, p. 185).

It is known that in the late nineteenth - early twentieth century Russia attempted several times to create the Institute of Accountants. Its charter was drafted by such personalities as E. G. Valdenberg, I. D. Hopfenhausen, A. M. Wolf, I. A. Zhidkov, F. V. Yezersky, F. I. Belmer, V. A. Brunner, A. I. Gulyaev, and V. D. Belov. These drafts outlined some parameters of the accounting profession, though never making it more certain. Pioneers of this idea had different views about professional grades, practical skills, and level of education characterising the profession.

Before the discussions about the Institute started, Belov identified two main types of accountants depending on the nature of their work: accounting organisers (whom he called 'artists and organisers') and accountants in charge of bookkeeping. The latter had to manage and supervise bookkeeping. At the same time bookkeeping itself could be entrusted to a clerk. The need for creative development of the profession was also highlighted by Sivers (1902), who was leading the St. Petersburg accounting school of thought at that time. He believed (1902, p. 136) that there had to be accounting organisers, accounting administrators, and academic accountants in the future.

In the drafts of the institutes, professional types of accountants were aligned with the typical hierarchy of white-collar jobs according to the complexity of duties and respective salary. Wolf (1895), for instance, singled out three groups of accountants: an accountant, senior assistant, and junior assistant. Later, when the provision on the Institute of Chartered Accountants was drafted (The materials for the project of the Institute of swan-in accountants, 1896), Wolf and Zhidkov being among the drafters, accounting positions were called after the English ones: Fellow of Charted Accountant (FCA), Associate of Chartered Accountant, and Article's clerk. FCA were authorised to take management positions, check the accuracy of books and records, manage and keep epy books, control and audit different companies and enterprises, establish private accounting agencies, and issue accounting audit certificates. Article's clerks could take management positions only in cases provided by the Board (managing body of the Institute); they were not entitled to open accounting agencies or issue accounting audit certificates. 
Similar terms could be found in the drafts prepared by Hopfenhausen and Yezersky, although radically different in general. Hopfenhausen, for instance, proposed three grades of Russian accountants identified as grade 1, grade 2, and grade 3. A separate grade included foreign accountants serving in Russia. Hopfenhausen's draft thoroughly outlined the rights and duties of accountants in accordance with civil and trade legislation of the Russian Empire. Relations between a hiring merchant and an accountant were supposed to be based on a contract. Meanwhile relations between different grades of accountants were based on hierarchy and mutual assistance.

Yezersky's draft, produced after the charter of the Society of Accountants established by him, brought relations based on respect for rank, so traditional for the imperial Russia, to the envisioned professional corporation. Society members included life, honourary (top officials acting as patrons), and full members. Later the society underwent further professionalisation, full members being split into two categories: "chartered accountants" and "associate members". The lists of chartered accountants were supposed to be annually published in the public recognition of their rights for professional practice (Tenth Anniversary of the Society of Accountants, 1902). The pursuance of support from influential individuals was also typical for the draft of Belmer, Brunner, and Gulyaev, founders of the Moscow Society of Accountants. Its members were classified as honorary, associate, accounting, and expert accounting members. Honorary members in both drafts were endowed with a special status: they were not bound by qualification or other requirements set for admission to the corporation (The First All-Russian Congress of Accountants. Institute of accountants in Russia, 1909).

Gradations of accounting positions were meant to bring order to the professional association, set up subordination, and define promotion prospects. At the same time this only scratched the surface of the problem, the deeper layers being related to determining an applicant's knowledge and skills. The first drafts of the Institute typically associated knowledge with education and accounting skills with the length of service.

According to Wolf and Zhidkov's draft, for instance, chartered accountants and chartered accountant assistants could be individuals who submitted certificates confirming that they had completed a course of commerce at a secondary (for an accountant assistant) or a higher (for a chartered accountant) educational institution (Materialy dlya proekta polozheniya Instituta prisyazhnyh buhgalterov, 1996). Applicants without commercial education were admitted only after an accounting exam. The fact itself that these requirements were articulated back in 1895, when courses of commercial sciences were given in just few educational institutions and commercial education was not developed as a vocational type of training yet, testifies to a promising nature of the project. Wolf and Zhidkov's chartered accountant was rather a prototype of the corporation full member. This differed from images developed by Belov and Sivers only by the context, an attempt to combine the rational (a document) with the irrational (an image).

Hopfenhausen's draft (1897) set requirements not only for an applicants' education, but also for their practical experience. Certificates from educational institutions also gave applicants some advantage, like in Wolf and Zhidkov's draft. Their holders were exempt from entrance exams if the course they had taken matched or even exceeded the exam programme. Hopfenhausen was the only one to propose exams not only in vocational but also in basic academic disciplines. Exams in vocational disciplines were provided only for applicants for grades 1 and 2, while exams in basic academic disciplines had to be passed by all applicants. The only exception was applicants with a degree, authors of accounting writings or candidates with many years of accounting experience. 
An individual could become a member of the lowest grade, grade 3, without any practical experience. In order to pass from grade 3 to grade 2, it was necessary to occupy such a position or work in such institutions so as to get practical knowledge of accounting for no less than three years. Then, after serving five more years as a grade 2 accountant and getting the skills of accounting managing and bookkeeping, one could apply for grade 1 .

Hopfenhausen, more than anyone else, linked Institute membership to an applicant's general level of education. From his perspective, a corporation member acquired some traces of a cultural activist on the economic ground. At the same time requirements related to general knowledge acted as a restraint designed to exclude uneducated applicants incapable of performing basic clerk duties. The role of a bearer and disseminator (sower) of economic knowledge could be handled only by members of grade 1, the supreme grade.

The drafts were generally characterised by some remoteness from reality: requirements to the future member exceeded the possibility of compliance. By the early twentieth century, this conflict escalated into a dispute around the draft of the Moscow Society of Accountants (presented by F. I. Belmer). A. F. Ignatyuk, who took part in these discussions, voiced a concern that accountants without respective education would lose their jobs. He said, "We will have to make all accountants take an exam and obtain a certificate, while throwing out all the other good folks into the street since the Institute of Chartered Accountants will oblige entrepreneurs to employ accountants from the Institute only" (The First All-Russian Congress of Accountants. Institute of accountants in Russia, 1909, p. 50). Thus, the fine line between a desire to make accountants an educated class and a desire to give broader access to the corporation was never found.

One can notice that in the drafts offered by Wolf and Zhidkov, Hopfenhausen, and Belmer requirements to the knowledge of commercial sciences were formulated irrespectively of any well-known theories or systems. Access to the corporation was granted if the applicant showed a certain level of vocational knowledge. But Yezersky's vision of the accounting corporation was different. To confirm their knowledge, applicants had to produce certificates confirming that they had finished a school or a course which taught bookkeeping according to all the existing systems (Desiatiletie Obshhestva Schetovodov, 1892). In the first place, this meant triple-entry bookkeeping, created by the corporation leader himself. By establishing an institute, he, among other things, was intending to win new supporters for his theory, transforming a scholarly controversy into a war of corporations. Since none of the drafts outlining an accounting institute in Russia in the late nineteenth - early twentieth century was finally implemented, the conflict between Yezersky's triple-entry bookkeeping and double-entry bookkeeping never went beyond the narrow circle of accounting scholars, and the division between them went down in history just as evidence of a fierce clash of ideas.

In the twenty first century, when analysing the century-old attempts to create an Institute of Accountants, one cannot but notice that the discussions about the profession at that time covered a very wide range of issues. They concerned not only criteria for admission to a professional corporation, but also the position of accountants in business and society, their professional ethics, etc. Institute pioneers actually tried to identify the profession and its representatives, and separate accountants from other clerks, rendering a new status to them.

Before the end of the nineteenth century, an accountant had been viewed by the Russian public as a typical representative of a small class of white-collar workers, usually treated negatively or with sympathy. Their work was regarded as a dull and uninviting occupation, especially for young people. A famous Moscow accountant G. A. Bakhchisaraytsev gave it a very vivid description (1905, p. 3): "Serving for a ten-rouble monthly wage at some ironmongery, eating food offered by the owner, sweeping the floor, cleaning and closing the 
shop or writing invoices in the course of many years, then keeping part of a stock book to finally become ill and dull in the family, in life and for life, though with a nice handwriting you cannot but agree that not every young man will imagine 'this' as an ideal for his character and mindset". Peculiarity and complexity related to the creation of a professional association of Russian accountants were also conditioned by the fact that it was meant to change selfawareness of its members.

Professional occupation of accountants was intended to be made loftier by a chartered accountant's oath. It was included in two different versions in two of the drafts. The first one was included in the draft provision on "The Institute of Bookkeepers and Chartered Accountants of the Empire" (compiled in 1897 under the aegis of the Ministry of Finance based on the drafts by Wolf, Zhidkov, and Hopfenhausen). Only after taking the oath could applicants finally become "chartered accountants" in the full sense of the word. The text of the oath addressed to God combined reasonable professional conduct, honesty, and conscientious discharge of duties in good faith (Provision on the Institute of Bookkeepers and Chartered Accountants of the Empire, 1897, p. 64):

\section{Chartered accountant's oath}

I make $a$ vow and swear by God the Almighty before His Holy Gospel and Life-giving Cross to carry out, to the extent of my knowledge, any duties entrusted to me by the authorities, not to commit anything contrary to good faith in commerce and industry, to protect the interest of my clients and other individuals and institutions whose affairs I will be entrusted with, and to execute honestly and bona fide all the duties of a chartered accountant assumed by me, bearing in mind that in all of the above I will be held accountable to the law and God at the Last Judgment. In witness whereof I kiss the Gospel and Cross of my Saviour. Amen.

For non-Christian believers the wording was changed according to their faith.

The second version of the oath made part of a provision on the All-Russian Union of Accountants and Society of Accountants of F. V. Yezersky. The text was different. There the vow to perform chartered accountant's duties honestly and bona fide was related to the commitment to keep the books "in accordance with the truth" (All-Russian Union of Chartered Accountants and Society of Accountants, 1900, p. 16):

\section{Chartered accountant's oath}

I make a vow and swear by God the Almighty before His Holy Gospel and Life-giving Cross to keep secret all the affairs entrusted to me, compile accounting reports, books, and records in accordance with the true state of affairs, and never to compile, sign or approve such that are not in accordance with the truth, and to execute honestly and bona fide all the duties of a chartered accountant assumed by me, bearing in mind that in all of the above I will be held accountable to the law and God at the Last Judgment. In witness whereof I kiss the Gospel and Cross of my Saviour. Amen.

Despite fundamental differences in the texts, both oaths to some extent set forth the principles of accountant's professional conduct, the procedure itself proving the willingness to follow them. This form of initiation into the profession put accountants alongside officers or attorneys, whose ethics was recognised as exemplary.

\section{Concluding Remarks}

Regrettably, not a single draft of the Accounting Institute produced in Russia at the turn of the twentieth century came to existence. It can be easily concluded that there was not enough time for this to happen: revolution breaking out in the early of the century changed many of the existing ideas. This conclusion, however, would be too banal and apologetic. The true reasons 
for such failure are deep below the surface. They are rooted in the very nature of the initiatives proposed by the Russian pre-revolutionary intelligentsia (which the drafters represented). Producing images and drafts was something of an end in itself, an illusion making them feel part of a phenomenon of public importance. This typical feature of the Russian intelligentsia was clearly underlined by S. V. Lurie in 1909. He wrote (1998, p. 293), "The mistake of our intelligentsia is that they did not have the vital instinct that would allow them to separate the absolute and the autotelic from the relative and the beneficial; nor did they have public education or practical experience which teach people to sensibly use general ideas and unconditional moral requirements".

At the same time discussions revolving around the accounting profession in the late nineteenth - early twentieth century went down in history. And this is not just because the Institute of Professional Accountants ${ }^{6}$ set up in 1997 is acknowledged as a successor and follower of the ideas of the past. When shaping the image of a modern accountant, we seek to determine the character of this profession and develop, perhaps, both a more vivid and a more appropriate understanding of its subject matter and its representatives, i.e. people with respective professional skills. However, in the Information Age, marked by IT technologies which changed the very concept of accounting profession, Russian society is still trammelled by the traditional, fossilised image of an accountant as of a minor official and a rather plain and boring person enslaved by routine. An apparent discrepancy between the subject matter and the image of accounting profession does not only put accountants themselves in an awkward position when their job is mentioned, but also hinders the development of the profession itself. An unfaithful image, like any wrong reference point, cannot show the right direction.

Idealistic images and concepts of the profession which arose at the moment of its advent such as 'cultural activist on the economic ground', 'artist and organiser', and 'commerce officer' still seem attractive. Though impractical if taken separately, each image implies traits required to form a modern concept of accounting profession personified by an extremely educated, scrupulously honest, and socially responsible person capable of making decisions. These seemingly obvious components of the profession have not been definitely recognised by society so far, which leaves grounds for discussing the way to bring 'the absolute' and 'the ideal' closer to 'the real' and 'the attainable' in the vision of accounting as a profession.

\section{Literature}

All-Russian Union of Chartered Accountants and Society of Accountants (1900). Journal of the Society of Accountants, August-September, pp. 8-20 [Всероссийский Союз присяжных счетоводов и Общества счетоводов].

Alver, J., Alver, L. (2016). Accounting education at Tartu University in 1632-1940", in V. V.

Kovalev, D. A. Lvova (Eds.), Essays on the Theory and History of Accounting. Moscow: Prospect, pp. 334-345.

Anderson, M., Edwards J. R., Chandler R. A. (2005). Constructing the 'well qualified' chartered accountant in England and Wales. The Accounting Historians Journal, vol. 32, no. 2, pp. 5-54.

Anderson, M., Walker, S. P. (2009). 'All sorts and conditions of men': The social origins of the founders of the ICAEW. The British Accounting Review, vol. 41, pp. 31-45.

\footnotetext{
${ }^{6}$ Now Institute of Professional Accountants and Auditors of Russia (IPB of Russia).
} 
Bahchisaraitsev, G. A. [G.A.B] (1905). To the question about further education of the trade school graduates. Kommersant, no. 10, pp. 1-5 [Бахчисарайцев Г. А. (Г.А.Б.) К вопросу о дальнейшем образовании окончивших торговые школы]. (in Russian)

Belov, V. D. (1893). The value of theory in accounting. Accountancy, vol. 7, no. 4, pp. 50-53 [Белов В. Д. Значение теории в бухгалтерии]. (in Russian)

Boys, P. (2004). The mystery of the missing members: the first 600 Chartered Accountants in England and Wales. Accounting Business \& Financial History, vol. 14, no. 1, pp. 29-52.

Boys, P. (1994), The origins and evolution of the accountancy profession. In: W. Habgood (Ed.), Chartered accountants in England and Wales. A Guide to Historical Records, Manchester University Press, Manchester, pp. 1-63.

Briston, R. J., Kedslie, M.J.M. (1986). Professional Formation: The Case of Scottish Accountants - Some Corrections and Some Further Thoughts. The British Journal of Sociology, vol. 37, no. 1, pp. 22-130.

Brown, R. (1905). A History of Accounting and Accountants. Edinburgh: T. C. \& E. C. Jack.

Carnegie, G. D. (2009). The development of accounting regulation, education and literature in Australia, 1788-2005. Australian Economic History Review, vol. 49, no. 3, pp. 276-301.

Clarke, P. (2008). The teaching of bookkeeping in nineteenth-century Ireland. Accounting, Business \& Financial History, vol. 18, no. 1, pp. 21-33.

Dahl, V. (1956). Explanatory Dictionary of the Live Great Russian Language. Moscow: State Publishing House of Foreign and National Dictionaries, vol. 2 [Даль В. Толковый словарь живого великорусского языка].

Edwards, J. R., Walker, S. P. (2010). Lifestyle, status and occupational differentiation in Victorian accountancy. Accounting, Organizations and Society, vol. 35, pp. 2-22.

Flegm, E.H. (1991). The relevance of history in accounting education: some observations. Journal of Accounting Education, vol. 9, pp. 355-363.

Hopfenhauzen, I.D. (1896). A Preliminary Draft of the Institute of Accountants. Accountancy, vol. 10, no. 20-21, pp. 305-310 [Гопфенгаузен И. Д. Предварительный проект Института бухгалтеров]. (in Russian)

ICAS (1954). A History of the Chartered Accountants of Scotland from the Earliest Times to 1954 (1984): Written and published on the occasion of the centenary of their Institute. Reprinted 1984 by Garland Publishing, New York.

Karelskaya, S., Zuga, E. (2015). Emerging of higher education institutions in the area of accounting in Russia. Audit Bulletin, no. 2, pp. 83-96 [Карельская С. Н., Зуга Е. И. Появление учебных заведений высшего бухгалтерского образования в России]. (in Russian)

Lee, T. (2004). Economic class, social status, and early Scottish chartered accountants. The Accounting Historians Journal, vol. 31, no. 2, pp. 27-51.

Lee, T. (1991). Review essay: professional foundations and theories of professional behavior. The Accounting Historians Journal, vol. 18, no 2, pp. 193-203.

Lurye, S. (1909). About the miscellany 'Milestones'. Russian Thought, vol. V, pp. 137-146 [Лурье С. О сборнике «Вехи»].

Macdonald, K. M. (1984). Professional formation: the case of Scottish accountants. British Journal of Sociology, vol. 35, no. 2, pp. 174-189. 
McMillan, K. P. (1999). The Institute of Accounts: a community of the competent Accounting. Business \& Financial History, vol. 9, no. 1, pp. 7-28.

Milyaev, N. A. (1890). About the Institute of Chartered Accountants. Accountancy, vol. 4, no. 19-20, pp. 184-185 [Миляев В. Об институте присяжных счетоводов]. (in Russian)

Ozhegov, S. I., Shvedova, N. Y (1992). Explanatory dictionary of Ozhegov. (1949-1992) available on-line at: http://www.ozhegov.org/words/7036.shtml [01 Sep 2016] [Ожегов С.И., Шведова Н.Ю. Толковый словарь Ожегова. 1949-1992]. (in Russian)

Provision on the Institute of Bookkeepers and Chartered Accountants of the Empire (1897) Accountancy, vol. 10, no. 4, pp. 62-63 [Положение об Институте бухгалтеров и присяжных счетоведов Империи]. (in Russian)

Ramirez, C. (2001), Understanding social closure in its cultural context: accounting practitioners in France (1920-1939). Accounting, Organizations and Society, vol. 26, no. 4/5, 391-418.

Renofanc, I. (1837). Pocket Book for the Lover of Reading Russian Books, Newspapers and Magazines. St. Petersburg [Ренофанц И. Карманная книжка для любителя чтения русских книг, газет и журналов]. (in Russian)

Sakharov, A. (1906). Our business schools and their social value Russian School, no 4, pp. 99-121 [Сахаров А. Наши коммерческие школы и их общественное значение]. (in Russian)

Shimanovsky, V. (1908). Parenting the merchant class. Commercial Education, no. 6, pp. 293-297 [Шимановский В. Воспитание купечества].

Sivers, E. E. (1902). On the preparation of Commercial Sciences teaching in business schools. In: Proceedings on Accounting Education. Issue. II. Commercial Schools, pp. 190-219 [Сиверс Е. Е. О подготовке преподавания коммерческих наук в коммерческих училищах]. (in Russian)

Sokolov, Y. V. (2003). The Image of the Accountant in Literature and Cinema. Moscow: ID FBC-Press [Соколов Я. В. Образ бухгалтера в литературе и кино]. (in Russian)

Tenth Anniversary of the Society of Accountants. 1892-1902. Anniversary edition (1902). St. Petersburg-Moscow [Десятилетие Общества счетоводов. 1892-1902. Юбилейное издание]. (in Russian)

The First All-Russian Congress of Accountants. Institute of accountants in Russia (1909). Moscow: Moscow Society of Accountants [Первый Всероссийский съезд бухгалтеров. Институт бухгалтеров в России]. (in Russian)

The materials for the project of the Institute of swan-in accountants. (1896). Accountancy, vol. 10, no. 19-20, pp. 280-286 [Материалы для проекта Положения Института присяжных бухгалтеров]. (in Russian)

The Ministry of Finance. 1802-1902. Part two. (1902). St. Petersburg: The Expedition of State Papers Storing, 1902 [Министерство финансов. 1802-1902].

Walker, S. P. (2004). The genesis of professional organisation in English accountancy. Accounting, Organizations and Society, vol. 29, pp. 127-156.

Walker, S. P. (1995). The genesis of professional organization in Scotland: a contextual analysis. Accounting, Organizations and Society, vol. 20, no. 4, pp. 285-310. 
Willmott, H. (1986). Organising the profession: a theoretical and historical examination of the development of the major accountancy bodies in the UK. Accounting, Organizations and Society, vol. 11, no. 6, pp. 555-580.

Wolf, A. M. (1895). The Corporation of book-keepers and swan-in accountants. Accountancy, vol. 9, no. 22-23, pp. 307-310 [Вольф А. М. Корпорация счетоводов и присяжные счетоведы]. (in Russian)

Zamyatin, P. (1893). Structure, purpose and importance of business education. Accountancy, no. 23, pp. 338-340 [Замятин П. Состав, цели и значение коммерческого образования]. (in Russian) 